\title{
Study of Cotton (Gossypium hirsutum L.) Crop Response to Irrigation, Fertigation and Drip Geometry
}

\author{
Harshad V. Vala ${ }^{1}$, V. K. Sardhara ${ }^{2}$ and Parth J. Kapupara ${ }^{3^{*}}$ \\ ${ }^{1}$ Agricultural Engineering, Junagadh Agricultural University, Junagadh, Gujarat, India \\ ${ }^{2}$ College of Agriculture, Junagadh Agricultural University, Amreli, Gujarat, India \\ ${ }^{3}$ Department of Agricultural Engineering, RK Universiry, Rajkot, Gujarat, India \\ *Corresponding author
}

\section{A B S T R A C T}

\section{Keywords}

Cotton, Irrigation, Fertigation, Yield, Drip

\section{Article Info}

Accepted:

18 December 2020

Available Online:

10 January 2021
Cotton (Gossypium hirsutum L.) has its unique reputation and name as the "King of fiber" and "White gold" because of its high economic value amongst cultivable crops. Cotton is a leading commercial and major cash crop of India. However, India's average yield of $541 \mathrm{~kg} / \mathrm{ha}$ (201617 ) is much lower than other top cotton growing nations. One of the main reasons for the low coverage of irrigation is the predominant usage of conventional technique of irrigation, where water use efficiency is very low. The irrigation efficiency can be enhanced by replacing surface irrigation with micro irrigation methods especially in arid and semi-arid regions. Water and fertilizer are the two important inputs for agricultural production and both have interacting effects on plant growth and yield. Since water and fertilizer are costly inputs, every effort must be made to enhance water and fertilizer use efficiency by reducing their wastage. So, attempts have been made in the present research work conducted at College of Agricultural Engineering and Technology, JAU, Junagadh during July, 2018 - February, 2019to study the response of Cotton (Gossypium hirsutum L.) crop to irrigation and fertigation and drip geometry. The experiment was undertaken with 9 treatments consisting of different combinations such as two irrigation levels $(0.75 \mathrm{IW} / \mathrm{ETc}$ and $1.0 \mathrm{IW} / \mathrm{ETc})$, two dripper geometry $(0.50 \mathrm{~m}$ spacing with 3 Lph discharge emitter and $0.60 \mathrm{~m}$ spacing with $4 \mathrm{Lph}$ discharge emitter) and two fertilizer level (75\% RDF and 100\% RDF). Large plot design was adopted with three replications for each treatment. The response of cotton was evaluated in terms of no. of balls per plant, seed cotton yieldand water use efficiency. Results revealed that the highest no. of balls (38.40) and seed cotton yield $(2569.38 \mathrm{~kg} / \mathrm{ha})$ were observed under dripper spacing of $0.60 \mathrm{~m}$ with $4 \mathrm{Lph}$ discharge emitter in combination with irrigation level 1.0 IW/ETc and fertilizer level of $100 \%$ RDF. The present study leads to conclude that the farmers should cultivate the cotton crop by applying irrigation and fertigation through drip system (16 mm lateral of $1.2 \mathrm{~m}$ spacing $\mathrm{x}$ 4Lph x $0.6 \mathrm{~m}$ emitter spacing) at $1.0 \mathrm{IW} / \mathrm{ETc}$ (3 days interval) and $100 \%$ RDF (N: P: K:: 240:050:150 kg/ha in 8 equal splits) for higher yield.

\section{Introduction}

Cotton (Gossypium hirsutum L.) has its unique fame and name as the "King of fiber" and "White gold" because of its high economic value among cultivable crops. Increasing the cotton production in India is the prime importance not only to meet the 
domestic and industrial demand but also to earn foreign exchange through export. As the scope for expansion of area under cotton cultivation is very much limited due to scarcity of water as well as need of land for food production, the only possible strategy is to increase the productivity of the existing cultivated area under cotton. Water and fertilizer are the two important inputs for agricultural production and both have interacting effects on plant growth and yield. Since water and fertilizer are costly inputs, every effort must be made to enhance water and fertilizer use efficiency by reducing their wastage.

Drip irrigation decrease input cost, increase yield, give additional water productivity than surface irrigation and lessen the hazard of yield fall due to inter-irrigation dry spells (Sivanappan, 2004). Relatively few studies were conducted to analyze the performance of drip irrigation system with different Irrigation and fertigation level and comparison among various dripper geometry on productivity of Bt. Cotton. Hence, present investigation was aimed at studying the feasibility of drip irrigation with various irrigation regimes and dripper geometry on productivity of Bt. Cotton.

\section{Materials and Methods}

A field experiment was conducted during at College of Agricultural Engineering and Technology, JAU, Junagadh during July, 2018 - February, 2019 to evaluate the conjunctive impact of dripper geometries (0.50 m spacing with $3 \mathrm{Lph}$ discharge emitter and $0.60 \mathrm{~m}$ spacing with $4 \mathrm{Lph}$ discharge emitter), two drip irrigation levels $(0.75$ IW/ETc, 1.0 IW/ETc) and two fertilizer levels (75\% RDF, 100\% RDF) and compared with farmer practices (100\% RDF and furrow irrigation method)on Gujarat cotton hybrid-8 (BG-II). The treatment table is presented in
Table 1. Large Plot Technique was adopted with nine treatment combinations. Each treatment was replicated thrice. Cotton was sown at $45 \mathrm{~cm} \times 120 \mathrm{~cm}$ spacing. On the same day of sowing, seeds were also sown separately in polybags which were used for gap filling at 10 Day after sowing. Standard agronomical practices recommended by University were followed.The details of agronomical practices are summarized in Table 2. The water-soluble fertilizers namely nitrogen and potassium in the form of urea and Muriate of potash, respectively, were dissolved in a tank as per the fertilizer treatments and applied directly with the irrigation water. Application of phosphorus $(100 \%$ RDF) in the form of single superphosphate was applied as a basal dose. The fertilizer dose in $\mathrm{kg}$ per hectare $(\mathrm{N}: \mathrm{P}: \mathrm{K})$ 240:050:150 as per the recommended dose of fertilizer (RDF) was $522 \mathrm{~kg}$ Urea, $312 \mathrm{~kg}$ Single Superphosphate and $250 \mathrm{~kg}$ Muriate of potash per hectare.

Application of recommended fertilizers was done as per the treatments at 15 days interval in 8 splits through fertigation. First fertigation was done after 32 days from the date of sowing. Irrigation was given at every third day in drip treatments whereas furrow method received 12 irrigations as per the conventional approach. The crop period of cotton is about 180 days. The first harvesting was done on 137 DAS and then second harvesting was done after 30 days. Cotton was picked manually from plants and yield attributes and water use efficiency were monitored.

\section{Treatment details}

\section{Treatments}

Factor-I: Irrigation Level $\left(\mathrm{I}_{\mathrm{i}}\right)$

$\mathrm{I}_{1}-0.75 \mathrm{IW} / \mathrm{ET}_{\mathrm{c}}$ $\mathrm{I}_{2}-1.0 \mathrm{IW} / \mathrm{ET}_{\mathrm{c}}$ 
Factor-II: Dripper Geometry $\left(\mathrm{S}_{\mathrm{i}}\right)$

$\mathrm{S}_{1}-0.50 \mathrm{~m}$ spacing with $3 \mathrm{Lph}$ discharge emitter

$\mathrm{S}_{2}-0.60 \mathrm{~m}$ spacing with $4 \mathrm{Lph}$ discharge emitter

Factor-III: Fertilizer Level (Fi)

$\mathrm{F}_{1}-75 \% \mathrm{RDF}$

$\mathrm{F}_{2}-100 \% \mathrm{RDF}$

\section{Results and Discussion}

\section{Seed cotton yield}

The data on the effect of irrigation level, dripper geometry and fertigation level on seed cotton yield is graphically depicted in Fig. 1.

\section{Effect of irrigation level on seed cotton yield}

It was found that the effect of irrigation level on seed cotton yield was significantly high. The highest seed cotton yield $(2430.71 \mathrm{~kg} / \mathrm{ha})$ was observed under treatment $\mathrm{I}_{2}\left(1.0 \mathrm{IW} / \mathrm{ET}_{\mathrm{c}}\right)$ and the lowest $(1938.72 \mathrm{~kg} / \mathrm{ha})$ in $\mathrm{I}_{1}(0.75$ $\mathrm{IW} / \mathrm{ET}_{\mathrm{c}}$ ).

\section{Effect of dripper geometry on seed cotton yield}

It was found that seed cotton yield was significantly affected by dripper geometry. The highest seed cotton yield $(2265.53 \mathrm{~kg} / \mathrm{ha})$ was observed under treatment $\mathrm{S}_{1}(0.50 \mathrm{~m}$ spacing with $3 \mathrm{Lph}$ discharge emitter) and the lowest $(2103.90 \mathrm{~kg} / \mathrm{ha})$ in $\mathrm{S}_{2}(0.60 \mathrm{~m}$ spacing with 4 Lph discharge emitter).

\section{Effect of fertigation level on seed cotton} yield

It was found that the seed cotton yield was significantly affected by different fertigation level. The highest seed cotton yield (2248.95 $\mathrm{kg} / \mathrm{ha}$ ) was observed under treatment $\mathrm{F}_{2}$ (100\% RDF) and the lowest $(2120.48 \mathrm{~kg} / \mathrm{ha})$ under treatment $\mathrm{F}_{1}$ (75\% RDF).

\section{Interaction effect on seed cotton yield}

Seed cotton yieldsignificantly influenced with interaction of irrigation level, dripper geometry and fertigation level. The highest seed cotton yield( $2569.38 \mathrm{~kg} / \mathrm{ha})$ was observed under the treatment combination $\mathrm{I}_{2} \mathrm{~S}_{2} \mathrm{~F}_{2}$ followed by $\mathrm{I}_{2} \mathrm{~S}_{1} \mathrm{~F}_{2}(2484.29 \mathrm{~kg} / \mathrm{ha})$ and $\mathrm{I}_{2} \mathrm{~S}_{1} \mathrm{~F}_{1}$ $(2403.70 \mathrm{~kg} / \mathrm{ha})$ respectively and lowest $(1744.92 \mathrm{~kg} / \mathrm{ha})$ under the treatment combination of $\mathrm{I}_{1} \mathrm{~S}_{2} \mathrm{~F}_{2}$. The increase in yield under drip fertigation with $100 \%$ RDF and 1.0 IW/ET $\mathrm{E}_{\mathrm{c}}$ might be due to enhanced availability and uptake of nutrients leading to enhancement in the process of photosynthesis, expansion of leaves and translocation of nutrients to reproductive parts compared to conventional method of nutrients application in the soil. Similar findings were also recorded by Gireesha(2003).

\section{Number of Balls (Opened Balls) Per Plant}

The data on the effect of irrigation level, dripper geometry and fertigation level on no. of balls per plant graphically depicted in Fig. 2.

Effect of irrigation level on no. of balls per plant: It was found that the effect of different irrigation level on no. of balls per plant were significantly high. The highest no. of balls per plant (32.05) were observed in I2 (1.0 IW/ETc) and the lowest no. of balls (24.41) was observed in I1 (0.75 IW/ETc).

Effect of dripper geometry on no. of balls per plant: It was found that there was no significant effect of dripper geometry on no. of balls per plant. 
Table.1 Details of treatment combinations

\begin{tabular}{|l|c|c|c|c|}
\hline \multicolumn{2}{|c|}{ Treatment } & Irrigation Level (I) & Dripper Geometry (S) & Fertilizer Level (F) \\
\hline $\mathbf{T}_{\mathbf{1}}$ & $\mathrm{I}_{1} \mathrm{~S}_{1} \mathrm{~F}_{1}$ & $0.75 \mathrm{IW} / \mathrm{ET}_{\mathrm{c}}$ & $3 \mathrm{Lph} \times 0.50 \mathrm{~m}$ & $75 \% \mathrm{RDF}$ \\
\hline $\mathbf{T}_{\mathbf{2}}$ & $\mathrm{I}_{1} \mathrm{~S}_{1} \mathrm{~F}_{2}$ & $0.75 \mathrm{IW} / \mathrm{ET}_{\mathrm{c}}$ & $3 \mathrm{Lph} \times 0.50 \mathrm{~m}$ & $100 \% \mathrm{RDF}$ \\
\hline $\mathbf{T}_{\mathbf{3}}$ & $\mathrm{I}_{1} \mathrm{~S}_{2} \mathrm{~F}_{1}$ & $0.75 \mathrm{IW} / \mathrm{ET}_{\mathrm{c}}$ & $4 \mathrm{Lph} \times 0.60 \mathrm{~m}$ & $75 \% \mathrm{RDF}$ \\
\hline $\mathbf{T}_{\mathbf{4}}$ & $\mathrm{I}_{1} \mathrm{~S}_{2} \mathrm{~F}_{2}$ & $0.75 \mathrm{IW} / \mathrm{ET}_{\mathrm{c}}$ & $4 \mathrm{Lph} \times 0.60 \mathrm{~m}$ & $100 \% \mathrm{RDF}$ \\
\hline $\mathbf{T}_{\mathbf{5}}$ & $\mathrm{I}_{2} \mathrm{~S}_{1} \mathrm{~F}_{1}$ & $1.0 \mathrm{IW} / \mathrm{ET}_{\mathrm{c}}$ & $3 \mathrm{Lph} \times 0.50 \mathrm{~m}$ & $75 \% \mathrm{RDF}$ \\
\hline $\mathbf{T}_{\mathbf{6}}$ & $\mathrm{I}_{2} \mathrm{~S}_{1} \mathrm{~F}_{2}$ & $1.0 \mathrm{IW} / \mathrm{ET}_{\mathrm{c}}$ & $3 \mathrm{Lph} \times 0.50 \mathrm{~m}$ & $100 \% \mathrm{RDF}$ \\
\hline $\mathbf{T}_{\mathbf{7}}$ & $\mathrm{I}_{2} \mathrm{~S}_{2} \mathrm{~F}_{1}$ & $1.0 \mathrm{IW} / \mathrm{ET}_{\mathrm{c}}$ & $4 \mathrm{Lph} \times 0.60 \mathrm{~m}$ & $75 \% \mathrm{RDF}$ \\
\hline $\mathbf{T}_{\mathbf{8}}$ & $\mathrm{I}_{2} \mathrm{~S}_{2} \mathrm{~F}_{2}$ & $1.0 \mathrm{IW} / \mathrm{ET}_{\mathrm{c}}$ & $4 \mathrm{Lph} \times 0.60 \mathrm{~m}$ & $100 \% \mathrm{RDF}$ \\
\hline $\mathbf{T}_{\mathbf{9}}$ & Control & Farmer Practices with $100 \% \mathrm{RDF}$ and furrow irrigation method \\
\hline
\end{tabular}

Table.2 Agronomical practices

\begin{tabular}{|c|c|c|}
\hline Sr. No. & Particulars & Details \\
\hline 1 & Crop & Cotton (Gossypium hirsutum L.) \\
\hline 2 & Variety & Gujarat cotton hybrid-8 (BG-II) \\
\hline 3 & Sowing Method & Manual \\
\hline 4 & Date of Sowing & $26 / 07 / 2018$ \\
\hline 6 & Crop spacing & $120 \mathrm{~cm} \times 45 \mathrm{~cm}$ \\
\hline 7 & Fertilizer dose (N: P: K) & 240:050:150 kg/ha \\
\hline 8 & Gap feeling & Gap feeling was done after 10 days of sowing \\
\hline 8 & Weeding & Manually (six time in a season) \\
\hline 9 & Irrigation practices & Three days interval as per treatments \\
\hline 10 & Fertigation & $\begin{array}{l}\text { Applied water soluble } \mathrm{N} \text { and } \mathrm{K} \text { fertilizer and solid } \mathrm{P} \\
\text { fertilizer as per treatment of a particular plot }\end{array}$ \\
\hline 11 & $\begin{array}{l}\text { Spraying pesticides, insecticides } \\
\text { and fungicides }\end{array}$ & Manually as per disease indication \\
\hline 12 & First Picking & $10-12-2018$ \\
\hline 13 & Last Picking & 10-01-2019 \\
\hline
\end{tabular}

Fig.1 Effect of irrigation level (I), dripper geometry (S) and fertigation level (F) on seed cotton yield

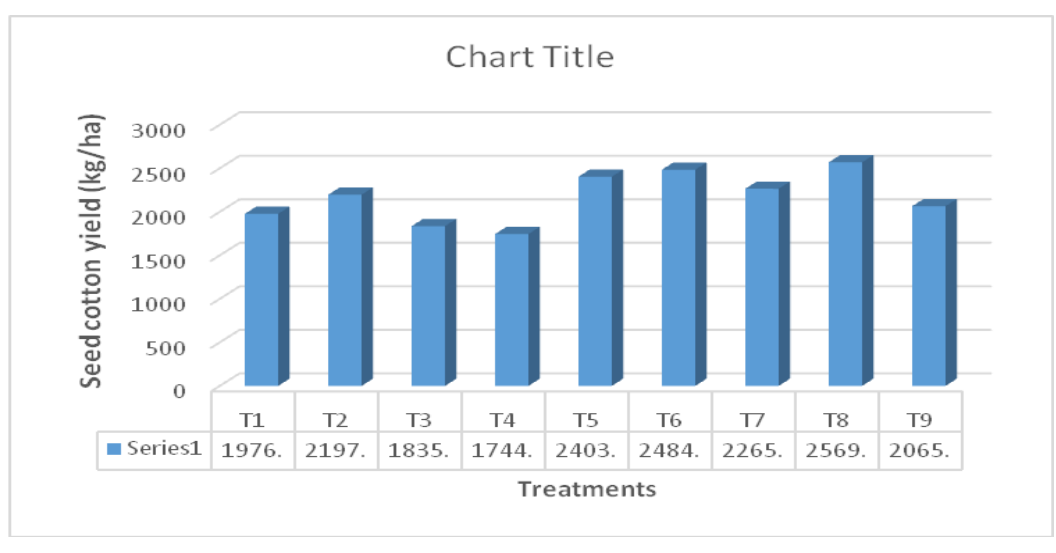


Fig.4.4.1 Effect of irrigation level (I), dripper geometry (S) and fertigation level (F) on no. of balls per plant

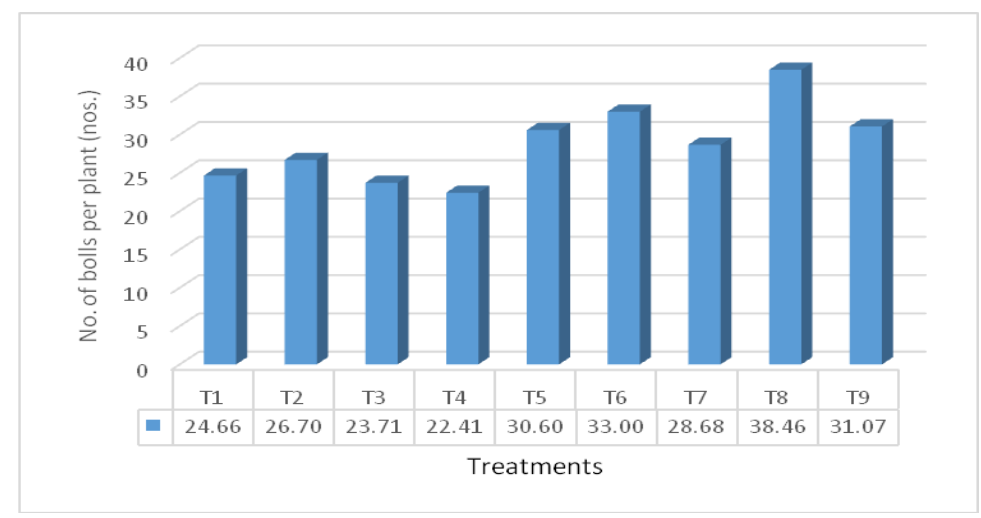

Fig.3 Effect of irrigation level (I), dripper geometry (S) and fertigationlevel (F) on water use efficiency

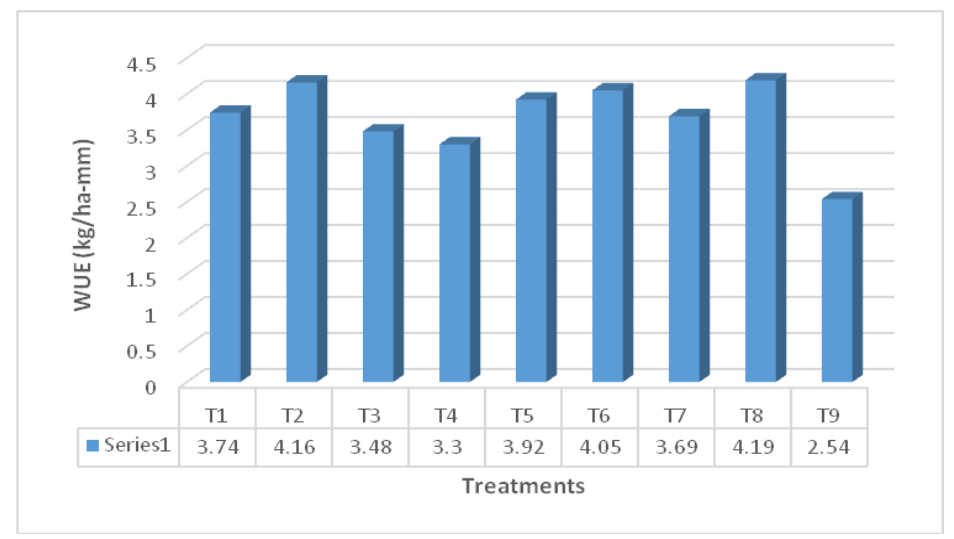

Effect of fertigation level on no. of balls per plant: It was found that the effect of fertigation level on no. of balls per plant were significantly high. The highest no. of balls per plant (29.51) were observed in F2 (100\% RDF) and the lowest no. of balls (26.95) was observed in F1 (75\% RDF).

Interaction effect on no. of balls per plant: No. of balls per plant significantly influenced with interaction of irrigation level, dripper geometry and fertigation level. The highest no. of balls per plant (36.07) was observed under the treatment combination $\mathrm{I}_{2} \mathrm{~S}_{2} \mathrm{~F}_{2}$ which was at par (33.22) withI $\mathrm{S}_{2} \mathrm{~S}_{1} \mathrm{~F}_{2}$. The Lowest no. of balls per plant (22.41) was observed under the combination of treatment $\mathrm{I}_{1} \mathrm{~S}_{2} \mathrm{~F}_{2}$. Drip irrigation method with $1.0 \mathrm{IW} / \mathrm{ETc}$ registered maximum number of bolls per plant over surface irrigation method. This is because in drip irrigation, water is applied in the vicinity of the root zone as per the demand of the crop which causes efficient utilization of added nutrients and translocation of photosynthates towards the reproductive part. These results are in accordance with Singh et al., (2007).

\section{Water use efficiency}

Water use efficiency is the yield of harvested crop produce achieved from the available water to the crop from rainfall, irrigation and soil water storage (Singh et al., 2010). Water use efficiency under different irrigation level, 
dripper geometry and fertigation level are depicted in Fig. 3.

During the crop season total 44 no. of irrigations were applied with $1.0 \mathrm{ET}_{\mathrm{c}}$ and 0.75 ET $_{c}$ according to treatments. Water use efficiency under different treatment varied from $2.54 \mathrm{~kg} / \mathrm{ha}-\mathrm{mm}$ to $4.19 \mathrm{~kg} / \mathrm{ha}-\mathrm{mm}$. Highest water use efficiency $(4.19 \mathrm{~kg} / \mathrm{ha}-\mathrm{mm})$ was observed under treatment $\mathrm{I}_{2} \mathrm{~S}_{2} \mathrm{~F}_{2}$ and lowest WUE was observed in control treatment $(2.54 \mathrm{~kg} / \mathrm{ha}-\mathrm{mm})$. Treatment $\mathrm{I}_{2} \mathrm{~S}_{2} \mathrm{~F}_{2}$ has higher water use efficiency because it is having higher seed cotton yield as compared to other treatments. Treatment $\mathrm{I}_{1} \mathrm{~S}_{1} \mathrm{~F}_{2}$ with $0.75 \mathrm{ET}_{\mathrm{c}}$ is having very less difference in water use efficiency compare to $\mathrm{I}_{2} \mathrm{~S}_{2} \mathrm{~F}_{2}$, which indicates that the better water use efficiency can also be achieved by deficit irrigation, Analogous results were found by other authors like Bronson et al., (2001), Nalayini et al., (2006). Similarly, drip irrigation system gave higher water use efficiency as compared to control irrigation method.

In conclusion the study revealed that the highest seed cotton yield was 2,569.38 kg/ha under treatment combination $\left(\mathrm{I}_{2} \mathrm{~S}_{2} \mathrm{~F}_{2}\right)$ irrigation level 1.0 IW/ETc, dripper spacing of $0.60 \mathrm{~m}$ having $4 \mathrm{Lph}$ discharge and fertigation level of $100 \%$ RDF. And the highest cotton plant height and no. of balls were observed under treatment combination $\left(\mathrm{I}_{2} \mathrm{~S}_{2} \mathrm{~F}_{2}\right)$ of irrigation level 1.0 IW/ETc, dripper spacing of $0.60 \mathrm{~m}$ having $4 \mathrm{Lph}$ discharge and fertigation level of $100 \%$ RDF. However the highest water use efficiency of $4.19 \mathrm{~kg} / \mathrm{ha} . \mathrm{mm}$ was observed under treatment combination $\left(\mathrm{I}_{1} \mathrm{~S}_{2} \mathrm{~F}_{2}\right)$ irrigation level 0.75 IW/ETc, dripper spacing of $0.60 \mathrm{~m}$ having 4 Lph discharge and fertigation level of $100 \%$ RDF. Thus, the present study leads to conclude that to achieve higher yield the farmers should cultivate the cotton crop by applying irrigation and fertigation through drip system (16 mm lateral of $1.2 \mathrm{~m}$ spacing $\mathrm{x}$ $4 \mathrm{Lph} \times 0.6 \mathrm{~m}$ ) at $1.0 \mathrm{IW} / \mathrm{ETc}$ (3 days interval) and $100 \%$ RDF (N: P: K:: 240:050:150 kg/ha in 8 equal splits).

\section{References}

Sivanappan, R. K. (2004). Irrigation and rainwater management for improving water use efficiency in cotton. In:Proceedings of the International Symposium on Strategies for Sustainable cotton production, A Global Vision. 23-25, November, 1998, Dharward, Karnataka, India.

Gireesha, G. 2003. Crop establishment studies to increase yield in irrigated cotton (cv. MCU 12). M.Sc. (Ag) Thesis. Tamil Nadu Agricultural University, Coimbatore.

Singh, M., Gumber, R. K., Brar, A. S. and Singh, M. 2007. Efficacy of fertilizer application in cotton under drip and flood irrigation system. The World Cotton Research Conference-4 held at Civil Centre in Lubbock, Texas, USA during September 10-14, 2007. pp. 1-8.

Singh, R., Kundu, D. K. and Bandyopadhyay, K. K. 2010. Enhancing agricultural productivity through enhanced water use efficiency. Journal of Agricultural Physics. 10(2): 1-15.

Nalayini, P., Raja, R. and Kumar, A. A. 2006. Evapotranspiration based scheduling of irrigation through drip for cotton (Gossypium hirsutum L.). Indian Journal of Agronomy. 51: 232-235.

Bronson, K. F., Onken, A. B., Keeling, J. W., Booker, J. D. and Torbert, H. A. 2001. Nitrogen response in cotton as affected by tillage system and irrigation level. Soil Science Society of America Journal. 65: 1153-1163. 
How to cite this article:

Harshad V. Vala, V. K. Sardhara and Parth J. Kapupara. 2021. Study of Cotton (Gossypium hirsutum L.) Crop Response to Irrigation, Fertigation and Drip Geometry. Int.J.Curr.Microbiol.App.Sci. 10(01): 2934-2940.

doi: https://doi.org/10.20546/ijcmas.2021.1001.339 